\title{
A Study Towards Awareness and Corrective Measures of HIV/AIDS in North-Western Part of Nigeria Through Statistical Assessment
}

\author{
Chiwa Musa Dalah ${ }^{1}$ and SinghV V ${ }^{2 *}$ \\ ${ }^{1}$ Department of Mathematics \& Statistics, Yobe State University, Nigeria \\ ${ }^{2}$ Department of Mathematics, Yusuf Maitama Sule University, Nigeria
}

Submission: May 26, 2018, 2018; Published: July 19, 2018

*Corresponding author: Singh V V, Department of Mathematics Yusuf Maitama Sule University, Kano, Nigeria; Email: singh_vijayvir@yahoo.com

\begin{abstract}
The effect of Human Immunodeficiency Virus/Acquired Immune deficiency syndrome (HIV/AIDS) global epidemic continue to emerge decades after the first wave of infection. One key aspect of controlling the epidemic is by enlightening the general public on the epidemic. That is on how it can be contracted and controlled. Since the start of the epidemic many measures have been taken by the government and non-governmental organizations to control the epidemic, but still, it continued to infect and kill many people. The measures taken include manufacturing antiretroviral drugs and therapy, using of condoms and enlightenment among others.Nigeria consists of thirty-six (36) states and the federal capital territory (FCT) Abuja, and these are grouped into six geopolitical zones. North-Western Nigeria consists of seven states (7) namely Jigawa, Kaduna, Kano, Katsina, Kebbi, Sokoto and Zamfara with a total population of about thirty-five million ( $35 \mathrm{~m}$ ). Secondary data from Federal Ministry of Health is used in finding out whether people of North-western Nigeria are aware of HIV/AIDS?Statistical methods and techniques are used in analyzing the data[1-5].

Keywords: HIV; AIDS; Awareness; North-Western Nigeria; Counselling; Testing; Vaccine; Virus; HIV infection; Treatment; Multiple sexual partners; Illiteracy; Reproductive health; Blood transfusion; Unborn child; Respondents; Avoiding sex; Immune deficiency; Antiretroviral drugs; Condoms; Urban \& rural areas

Abbreviations: FCT: Federal Capital Territory; HIV/AIDS: Human Immunodeficiency Virus/Acquired Immune deficiency syndrome; CSO: Civil Society Organizations; NASCP: National AIDS and STDs Control Programme; NEACA: National Expert Advisory Committee on AIDS; HEAP: HIV \& AIDS Emergency Action Plan; NNRIMS: Nigeria National Response Information Management System; NSF: National Strategic Framework; UA: Universal Access;PLWHAs: people living with HIV and AIDS; RH: reproductive health; SACA: State Agencies for the Control of Aids; HUFFPED: Humanity Family Foundation for Peace and Development; LSACA: Lagos State AIDS Control Agency; NARHS: National HIV \& AIDS and Reproductive Health and Serological Survey
\end{abstract}

\section{Introduction}

HIV/AIDS (Human Immunodeficiency Virus/Acquired Immune Deficiency Syndrome) has affected many people in the world leading to their death since the early 1980s. The number of people affected by the virus continues to rise, and many attempts have been made to produce drugs/vaccine to control the virus, but up to now, a concrete solution has not been found. Nigeria has passed through several phases in her response to the AIDS epidemic. The stages included an initial period of denial, a large health sector response, and now a multi-sectoral response that focuses on prevention, treatment, and mitigation of impact interventions and divorces coordination and implementation as distinct response components. A central body is dedicated to leading and coordinating the response, while the various sectors, including civil society organizations (CSO), faith-based organizations and networks of people living with HIV and AIDS support groups focus on packaging and implementing interventions based on a national action plan[3,4].
The health response commenced with the setting up of an ad hoc National Expert Advisory Committee on AIDS (NEACA) in 1987. By 1988, the National AIDS and STDs Control Programme (NASCP) was formally established, with state counterparts set up after that to organize as well as to coordinate all HIV and AIDS activities at national and state levels. Federal Ministry of Health's HIV \& AIDS division and High-risk groups including brothel-based sex workers, non-brothel based sex workers, men having sex with men, injecting drug users, uniformed servicemen (Armed forces and Police) and transport workers, (Formerly known as NASCP) played a key role in developing guidelines on key interventions and monitoring of the epidemic. In 1997, the National Council on Health formally endorsed the multi-sectoral approach, and in 2000 the Federal Government of Nigeria commenced the implementation of this approach with the establishment of a Presidential Council on AIDS (PCA) and National Action Committee on AIDS (NACA). 


\section{Global Journal of Reproductive Medicine}

NACA has been transformed from a committee to an agency and now called National Agency for the Control of AIDS (NACA), for effective coordination of the national multi-sectoral response to HIV \& AIDS. An HIV \& AIDS Emergency Action Plan (HEAP) was initiated in 2001 which ran through 2004. The partners involved in implementing the plan included governmental institutions, non-governmental organizations, community-based organizations, faith-based organizations and persons living with or affected by HIV and AIDS. As part of renewed efforts, Nigeria launched a revised HIV and AIDS policy and a five year (20042008) National HIV and AIDS Behaviour Change Communication Strategy in 2003 and 2004, respectively[6-8].

The country also launched the Nigeria National Response Information Management System (NNRIMS) for HIV and AIDS (NACA, 2004).The NNRIMS has been reviewed, and an operational plan (2007 - 2010) has been developed. Failure of access to HIV \& AIDS treatment and services by the people needing them has prompted a rapid scale-up of the national response and made it appropriate to align the NNRIMS framework with issues articulated in the National Strategic Framework (NSF) as well as in the Nigeria road map moving towards Universal Access (UA) for prevention, treatment and support. This is done in collaboration with donors and partner. The Federal Ministry of Health has recently undertaken an intensive review of health sector HIV and AIDS response and developed the Health Sector Strategic Plan. The HIV and AIDS National Strategic Framework for Action (2005-2009) was developed under the leadership of NACA to replace HEAP with the intention of significantly scaling up the anti-retroviral treatment programme. The country also completed a policy document titled "Plan to scale-up antiretroviral treatment for HIV and AIDS in Nigeria2005-2009" with the overarching goal of improving the survival, quality of life and productivity of people living with HIV and AIDS (PLWHAs) [9].

The Nigerian government has also continued to be pro-active in its efforts to confront the HIV scourge with its overarching strategy elaborated in the bottom-up, poly-stakeholder and multi-sectoral National Strategic Plan (NSP). The NSP is derived from the architecture of the National Strategic Framework 201015 (NSF II) and has targets to halt and begin to reverse the spread of HIV infection, as well as mitigate the impact of HIV \& AIDS by 2015 . With the condition that where appropriate, the targets of the NSP should be population-based, the Federal Government of Nigeria implicitly recognizes HIV care and treatment as national public health good.

HIV prevalence in Nigeria is high considering the huge population (about 170 million) and the rate is higher than that of sub - Saharan African estimate of 3.4\% (PRB, 2012). About 3.5 million people in Nigeria are estimated to be living with HIV/ AIDS, and the estimated number of new infections and HIV/ AIDS-related deaths was 390,000 and 217,000 respectively in 2013 (General Population Survey, 2013).There is a slightly higher HIV prevalence in the rural areas $(3.6 \%)$ than in the urban areas (3.2\%). The distribution of the epidemic varies from region to region with the south-south zone $(5.5 \%)$ and lowest in the south-east (1.8\%). In Northeastern Nigeria where most of the people live in rural areas, the spread of HIV/AIDS causes includes sexual activities of adolescents and young adults polygamy and multiple sexualpartners, illiteracy, ignorance and poverty. According to Baker et al. [10], many research findings have shown that higher education level is associated with lower level of risk of being infected with HIV/AIDS.This study will attempt to find out are people of Northern Nigeria aware of HIV/ AIDS. The objective is to enlighten them so that the spread of the epidemic can be reduced among them[11].

\section{Awareness of HIV/AIDS among Nigerians}

Good health is basic to human welfare and is a fundamental objective of social and economic development. HIV \& AIDS and poor reproductive health (RH) still constitute major challenges to health and development in Nigeria. Addressing health challenges starts with identifying the problems, their causes, and determinants.The health environment is ever changing and shaped by new science, information, policies and sociocultural forces.Thus, there is the need to actively continue the collection of reliable data on health knowledge, attitude and the magnitude of the HIV \& AIDS epidemic[12]. This is necessary for us to improve our understanding of changing prevention needs, challenges and opportunities as well as stimulate appropriate public health action. This will ensure that on-going interventions and our future direction in policy formulation and programme development remain evidence-based. Scientific evidence must be incorporated into making management decisions, developing policies and implementing programmes to recognize and respond effectively to health problems.

Nigeria has undoubtedly made some progress over the years in containing and creating awareness on the scourge of HIV/ AIDS. Many lives have been saved through the awareness campaigns and provision and access to the antiretroviral (AVR) drugs for people living with HIV/AIDS. There are Federal and State agencies created and charged with the responsibilities of handling HIV/AIDS issues. (National Agency for the Control of Aids (NACA) and State Agencies for the Control of Aids (SACA).However, research shows that only a quarter of children living with HIV have access to antiretroviral therapy, and in some countries, coverage for children is half the coverage for adults $[13,14]$.

Available statistics indicate that up to 50 percent of children living with HIV/AIDS may die before their second birthday and 80 percent before their fifth birthday due to lack of access. Research has also shown that more than three million children are living with HIV with nearly 90 percent of them in sub-Saharan Africa, even as efforts to reach children and adolescents living with HIV have not moved as fast as that of adults. However, many still live without knowing their status, even as stigmatization remains an issue.As part of efforts to raise the bar on HIV/AIDS 


\section{Global Journal of Reproductive Medicine}

awareness in the country, Humanity Family Foundation for Peace and Development (HUFFPED) in partnership with Lagos State AIDS Control Agency (LSACA) and ActionAid recently organized the international AIDS conference tagged: "Stepping up towards HIV-free Nigeria."Experts, however, argue that there is need to increase awareness of HIV /AIDS and create the enabling environment that will give people living with HIV/AIDS a sense of belonging in the society, even as the government also needs to ensure the availability of the antiretroviral drugs to those that need them[15].

\section{The significance of the study}

This study is very significant because the outcome will give an idea on what to do on HIV/AIDS in northern Nigeria to reduce its infection. If the result shows a high percentage of awareness, public enlightenment should continue but if it is low, then enlightenment and counselling should be intensified, and standard medical facilities and qualified medical personnel should be deployed to these areas by the government and non-governmental organizations to control the spread of the epidemic.

\section{Methodology}

\section{Study design}

In this study, secondary data collected from the Federal ministry of health through National HIV \& AIDS and Reproductive Health and Serological Survey (NARHS Plus) used. The survey is

a cross-sectional study covering sampled individuals in NorthWestern Nigeria according to state.

\section{Results}

The results and analysis on awareness, knowledge of HIV/ AIDS, how it is spread, how it can be prevented, misconceptions about transmission and prevention of HIV and respondents' assessmentof their risk of contracting HIV by states in NorthWestern Nigeria are presented in tables and chats for easy understanding and interpretation[16].

Respondents were asked whether they have heard of HIV/AIDS and thought there was a cure for it. The results are presented in Table 1 and Figure 1. Eighty-five percent (85\%) of the respondents reported that they have heard of HIV/ AID and are aware of it and about Sixty-three percent (63\%) reported that AIDS has no cure. Only about sixteen percent $(16 \%)$ reported that AIDS does have a cure and about twentyone percent $(21 \%)$ reported that they have not heard of AIDS. This proportion was highest among the respondents with higher educational attainment compared to those with no formal education but about the same proportion for females and males, as well as respondents from rural and urban areas.From the previous analysis which has shown that awareness about HIV/ AIDS is high in the whole of North-Western Nigeria, the analysis according to the states has also proved that with Kaduna state having the highest percentage of awareness. The results are presented in Table 2 and Figure $2[17,18]$.

Table 1: Percentage Distribution of Respondents Reporting Awareness and knowledge of HIV \& AIDS and its Cure by State in North-Western Nigeria.

\begin{tabular}{|c|c|c|c|c|c|c|}
\hline \multirow[b]{2}{*}{ S/No } & \multirow[b]{2}{*}{ States } & \multicolumn{2}{|c|}{ AWARENESS } & \multicolumn{2}{|c|}{ KNOWLEDGE } & \multirow[b]{2}{*}{$\begin{array}{c}\text { Number of Men \& } \\
\text { Women interviewed }\end{array}$} \\
\hline & & $\begin{array}{c}\text { Heard of } \\
\text { HIV or AIDS }\end{array}$ & $\begin{array}{c}\text { AIDS does not have a } \\
\text { cure }\end{array}$ & $\begin{array}{l}\text { AIDS does have } \\
\text { a cure }\end{array}$ & $\begin{array}{l}\text { Don't know/have } \\
\text { heard of AIDS }\end{array}$ & \\
\hline 1 & Jigawa & 83.5 & 57.4 & 29.9 & 12.7 & 756 \\
\hline 2 & Kaduna & 99 & 76.1 & 17.7 & 6.2 & 919 \\
\hline 3 & Kano & 90.4 & 68.2 & 8.8 & 23 & 762 \\
\hline 4 & Katsina & 92.3 & 40.2 & 24.6 & 35.2 & 628 \\
\hline 5 & Kebbi & 75.8 & 67.6 & 9.3 & 22.9 & 728 \\
\hline 6 & Sokoto & 84.4 & 62.3 & 9.9 & 27.9 & 756 \\
\hline 7 & Zamfara & 69.9 & 71.4 & 9.3 & 19.3 & 658 \\
\hline \multicolumn{2}{|c|}{ TOTAL } & 85 & 63.3 & 15.6 & 21 & 5,207 \\
\hline
\end{tabular}

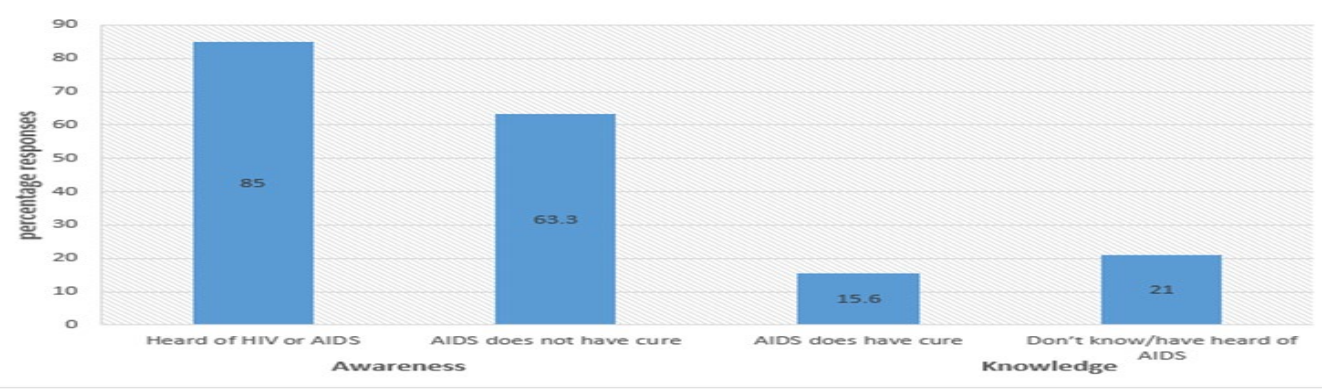

Figure 1: Percentage distribution of Respondents reporting awareness, knowledge and cure of HIVIAIDS. 
Table 2: Percentage Distribution of Respondents Reporting Awareness of HIV \& AIDS and its Cure by the state in North-Western Nigeria.

\begin{tabular}{|c|c|c|c|c|}
\hline \multirow{2}{*}{ S/No. } & \multirow{2}{*}{ States } & \multicolumn{2}{|c|}{ Awareness } & Number of men \& women \\
interviewed & AIDS does not have cure & 756 \\
\cline { 3 - 5 } & & Heard of HIV or AIDS & 57.4 & 919 \\
\hline 1 & Jigawa & 83.5 & 76.1 & 762 \\
\hline 3 & Kaduna & 99 & 68.2 & 628 \\
\hline 4 & Kano & 90.4 & 40.2 & 728 \\
\hline 5 & Katsina & 92.3 & 67.6 & 756 \\
\hline 6 & Kebbi & 75.8 & 62.3 & 71,4 \\
\hline
\end{tabular}

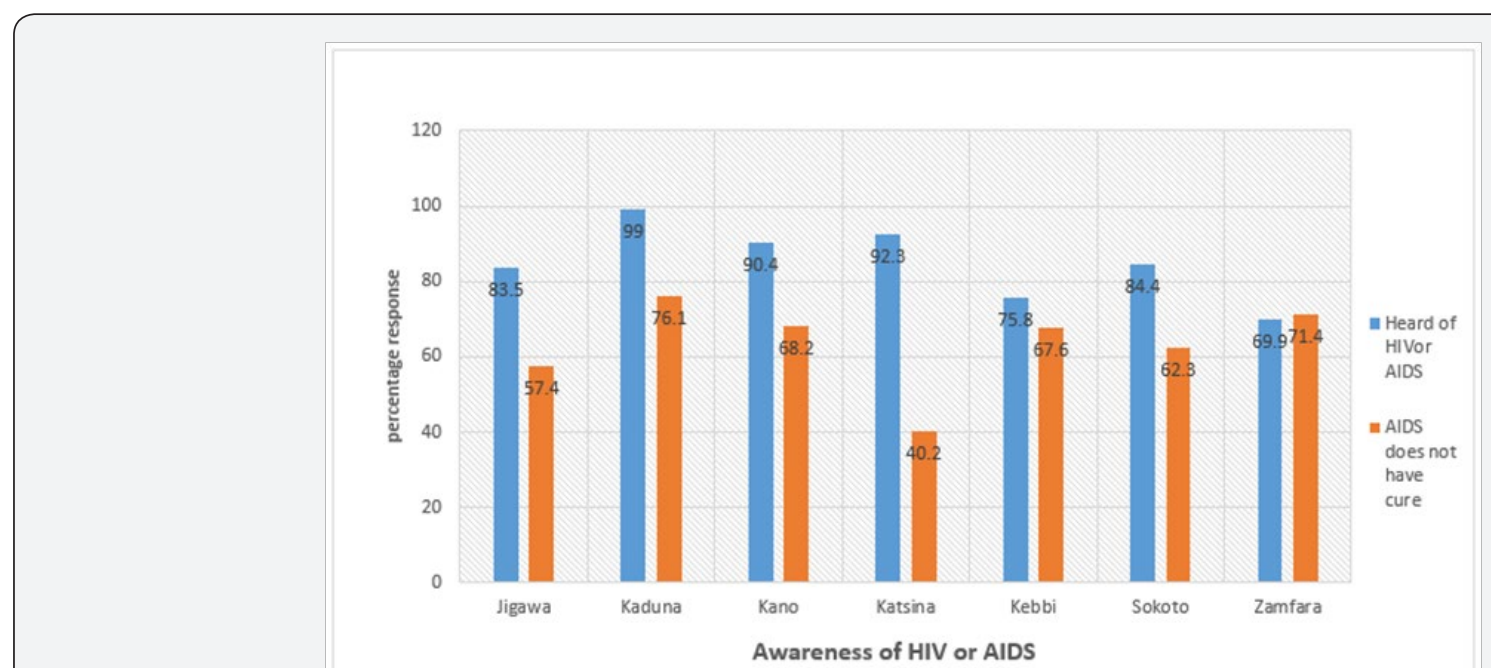

Figure 2: Percentage distribution of Respondents reporting awareness, knowledge and cure of HIVIAIDS.

Respondents were asked whether they know how a person can get the virus that causes AIDS. The results are presented in Table 3 and Figure 3 . About eighty percent (80\%) reported that they know that it can be gotten through sexual intercourse, sixtytwo percent $(62 \%)$ reported through blood transfusion. About forty-seven percent $(47 \%)$ reported through mother to unborn child, and about seventy-one percent $(71 \%)$ reported that it could be contracted through sharing of sharp objects like a razor.
Sixty-four percent (64\%) reported through sharing of needles. About forty-two percent (42\%) of the respondents reported that they know of the all five ways that a person can contract the virus that causes AIDS. This proportion was highest among the respondents with higher educational attainment compared to those with no formal education but about the same proportion for females and males, as well as respondents from rural and urban areas[19,20].

Table 3: Percentage Distribution of Respondents who know how a person can get the virus that causes AIDS by State in North-Western Nigeria.

\begin{tabular}{|c|c|c|c|c|c|c|c|c|}
\hline S/No & States & $\begin{array}{c}\text { Sexual } \\
\text { intercourse }\end{array}$ & $\begin{array}{c}\text { Blood } \\
\text { transfusion }\end{array}$ & $\begin{array}{c}\text { Mother to } \\
\text { unborn child }\end{array}$ & $\begin{array}{c}\text { Sharing sharp } \\
\text { objects like } \\
\text { razors }\end{array}$ & $\begin{array}{c}\text { Sharing } \\
\text { needles }\end{array}$ & Know all five & $\begin{array}{c}\text { Number of Men } \\
\text { \&Women interviewed }\end{array}$ \\
\hline 1 & Jigawa & 76.8 & 66.7 & 44.8 & 71.5 & 67.2 & 41.1 & 906 \\
\hline 2 & Kaduna & 98.7 & 91.6 & 73 & 95.8 & 90.4 & 67.2 & 928 \\
\hline 3 & Kano & 89.2 & 61.6 & 40.9 & 80.5 & 72.6 & 38 & 843 \\
\hline 4 & Katsina & 82.2 & 68.1 & 51.4 & 67.6 & 58.3 & 40.3 & 680 \\
\hline 5 & Kebbi & 67.1 & 43.9 & 31.6 & 51 & 45.5 & 28.5 & 959 \\
\hline 6 & Sokoto & 81.8 & 67.9 & 60.8 & 77 & 71.6 & 55 & 895 \\
\hline 7 & Zamfara & 61.8 & 36.7 & 25.3 & 56.6 & 42.8 & 23.5 & $\mathbf{4 1 . 4}$ \\
\hline \multicolumn{2}{|c|}{ TOTAL } & $\mathbf{7 9 . 7}$ & $\mathbf{6 2 . 4}$ & $\mathbf{4 6 . 8}$ & $\mathbf{6 4 . 1}$ & $\mathbf{4 1 . 9}$ & 941 \\
\hline
\end{tabular}




\section{Global Journal of Reproductive Medicine}

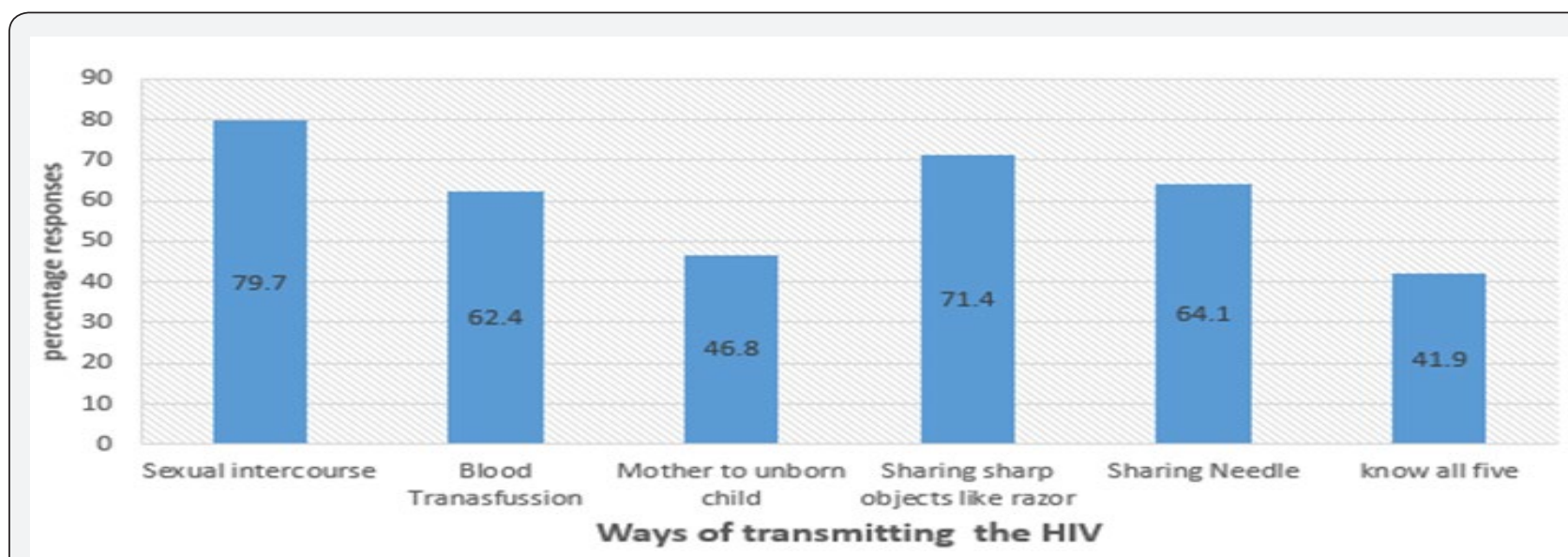

Figure 3: Percentage distribution of Respondents who know how a person can get the virus that causes AIDS.

Respondents were asked whether they know ways of preventing HIV infection. The results are presented in Table 4 and Figure 4. About seventy-four percent (74\%) reported that they know that it can be prevented by staying with one uninfected partner. About thirty-eight percent $(38 \%)$ reported that it could be prevented by using a condom every day. Fifty-nine percent (59\%) reported that it could be prevented by abstaining from sex. About sixty-two percent (62\%) reported it could be prevented by avoiding sex with commercial sex workers (CSW). Fifty-three percent (53\%) reported that it could be prevented by reducing the a number of sexual partners. About Sixty percent (60\%) reported that it could be prevented by avoiding sex with people with multiple sexual partners and about sixty-seven percent $(67 \%)$ of the respondents reported that it could be prevented by avoiding sharing sharp objects. This proportion was highest among the respondents with higher educational attainment compared to those with no formal education.Respondents were

Table 4: Percentage Distribution of Respondents' Knowledge of ways of preventing HIV infection by states in North-Western Nigeria.

\begin{tabular}{|c|c|c|c|c|c|c|c|c|c|}
\hline S/No & States & $\begin{array}{c}\text { Stay } \\
\text { with one } \\
\text { uninfected } \\
\text { partner }\end{array}$ & $\begin{array}{l}\text { Use of condom } \\
\text { every day }\end{array}$ & $\begin{array}{l}\text { By abstaining } \\
\text { from sex }\end{array}$ & $\begin{array}{l}\text { Avoid sex with } \\
\text { CSWs }\end{array}$ & $\begin{array}{l}\text { By reducing } \\
\text { no. of sexual } \\
\text { partners }\end{array}$ & $\begin{array}{l}\text { By avoiding } \\
\text { sex with } \\
\text { people with } \\
\text { multiple } \\
\text { sexual part- } \\
\text { ners }\end{array}$ & $\begin{array}{c}\text { By avoiding } \\
\text { sharing } \\
\text { of sharp } \\
\text { objects }\end{array}$ & $\begin{array}{c}\text { No. of men } \\
\text { \& women }\end{array}$ \\
\hline 1 & Jigawa & 70.2 & 20.2 & 40 & 58.2 & 46.6 & 60.8 & 68.1 & 906 \\
\hline 2 & Kaduna & 97.9 & 79.2 & 88.3 & 79 & 78.8 & 85.6 & 95.7 & 928 \\
\hline 3 & Kano & 85.1 & 38.7 & 70 & 75.8 & 59.2 & 72.1 & 80.6 & 843 \\
\hline 4 & Katsina & 76 & 26 & 66.9 & 60.2 & 58.4 & 56.2 & 54.9 & 680 \\
\hline 5 & Kebbi & 57.1 & 23 & 36.7 & 44.7 & 24.9 & 34.4 & 49.5 & 959 \\
\hline 6 & Sokoto & 78.3 & 51.5 & 64.4 & 75.4 & 65.8 & 69 & 74.3 & 895 \\
\hline 7 & Zamfara & 54 & 25.8 & 49.1 & 42.5 & 38.3 & 43.4 & 47.9 & 941 \\
\hline \multicolumn{2}{|c|}{ TOTAL } & 74.1 & 37.8 & 59.3 & 62.3 & 53.1 & 60.2 & 67.3 & 6,152 \\
\hline
\end{tabular}

asked about ways of transmitting HIV. Among the respondents interviewed about seventeen percent $(17 \%)$ thought it could be transmitted by sharing toilets. About seventeen percent (17\%) thought it could be transmitted by sharing utensils like a spoon, dish, plate, etc. and about seventeen percent (17\%) thought it could be transmitted by mosquito bites and bed bugs. Only about ten percent (10\%) thought it. The effect of Human Immunodeficiency Virus/Acquired Immune deficiency syndrome(HIV/AIDS) global epidemic continue to emerge decades after the first wave of infection. One keyaspect of controlling the epidemic is by enlightening the general public on the epidemic. That ison how it can be contracted and controlled. Since the start of the epidemic many measures havebeen taken by government and non-governmental organizations to control the epidemic but still itcontinued to infect and kill many people[21,22]. 


\section{Global Journal of Reproductive Medicine}

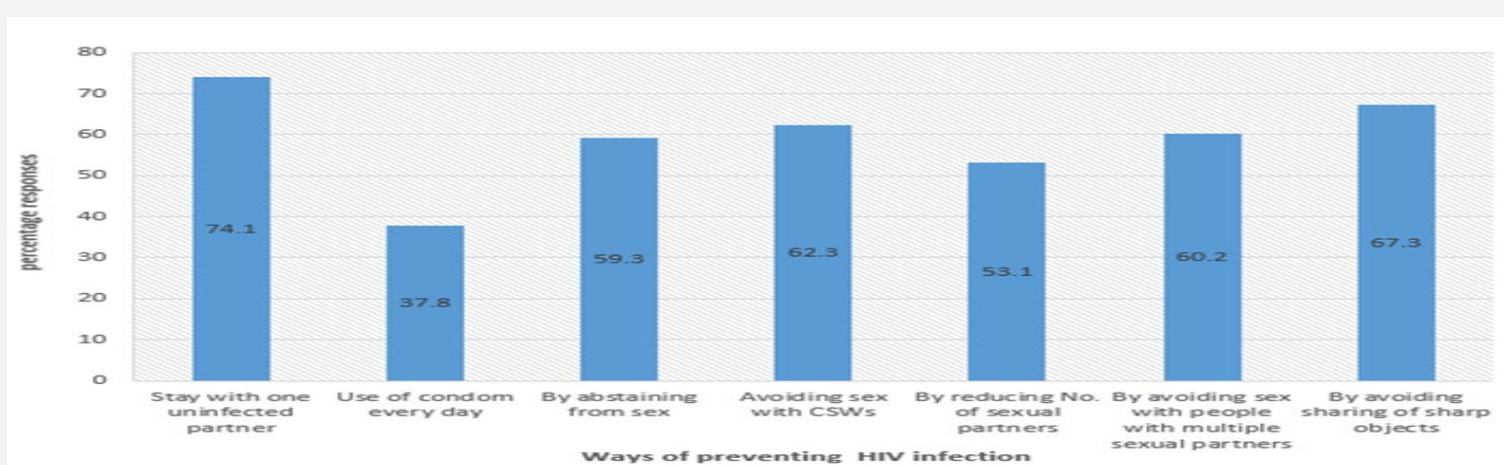

Figure 4: Percentage distribution of Respondents who have knowledge ofpreventing HIV infection.

The measures taken includes manufacturing antiretroviraldrugs and therapy, using of condoms and enlightment among others. Nigeria consist of thirty-six(36) states and the federal capital territory (FCT) Abuja, and these are grouped in to six geopoliticalzones. North-Western Nigeria consist of seven states (7) namely Jigawa, Kaduna, Kano, Katsina,Kebbi, Sokoto and Zamfara with a total population of about thirty-five million (35m). Secondarydata from Federal Ministry of Health is used in finding

Table 5: Percentage Distribution of Respondents who had Misconception about HIV transmission by State in North-Western Nigeria.

\begin{tabular}{|c|c|c|c|c|c|c|c|}
\hline S/No & States & $\begin{array}{c}\text { By sharing } \\
\text { toilet }\end{array}$ & $\begin{array}{c}\text { By sharing eating } \\
\text { utensils }\end{array}$ & $\begin{array}{c}\text { By mosquito bites/ } \\
\text { bed bugs }\end{array}$ & $\begin{array}{c}\text { By } \\
\text { witchcraft }\end{array}$ & $\begin{array}{c}\text { By } \\
\text { Kissing }\end{array}$ & $\begin{array}{c}\text { Men \& Women who } \\
\text { have heard of AIDS }\end{array}$ \\
\hline 1 & Jigawa & 13.7 & 15.9 & 23.2 & 16.4 & 25.7 & 756 \\
\hline 2 & Kaduna & 13 & 14.9 & 20.8 & 13 & 20.1 & 919 \\
\hline 3 & Kano & 11.9 & 9.7 & 13.3 & 4.3 & 15 & 762 \\
\hline 4 & Katsina & 14.8 & 12.1 & 17.8 & 4.8 & 7.3 & 628 \\
\hline 5 & Kebbi & 15 & 12.9 & 12.5 & 2 & 15 & 728 \\
\hline 6 & Sokoto & 29.5 & 29.1 & 13.5 & 14.8 & 23 & 756 \\
\hline 7 & Zamfara & 21.2 & 20.8 & 16.7 & 14 & 19.9 & \\
\hline \multicolumn{2}{r}{ TOTAL } & $\mathbf{1 7}$ & $\mathbf{1 6 . 5}$ & $\mathbf{1 6 . 8}$ & $\mathbf{9 . 9}$ & $\mathbf{1 8}$ & $\mathbf{5}$ \\
\hline
\end{tabular}

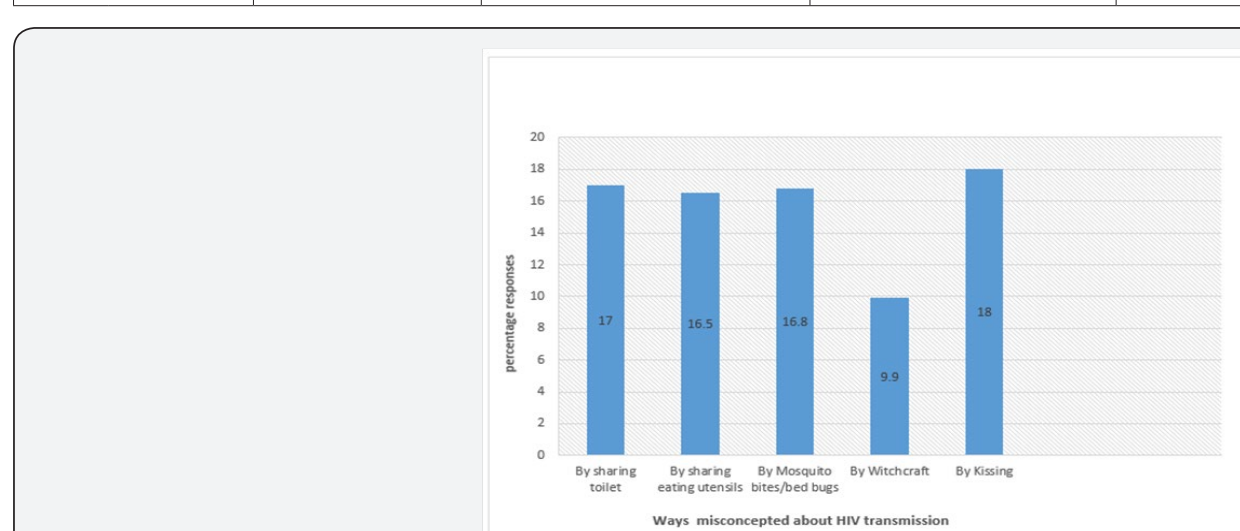

Figure 5: Percentage distribution of Respondents who had misconception about HIV transmission.

Respondents were asked about their risk of contracting HIV. Among the respondents interviewed about one percent (1\%) have a high chance of contracting the virus and about thirty-one percent (31\%) reported low chance. Fifty-one percent (51\%) reported no risk at all, and less than one percent $(0.4 \%)$ have aids while about seventeen percent (17\%) no response[23]. The results are presented in Table 6 and Figure 6. The results have out whether people of North-westernNigeria are aware of HIV/ AIDS? Statistical methods and techniques are used in analysing thedatacould be transmitted by witchcraft while about eighteen percent $(18 \%)$ thought it could be transmitted by kissing. The percentages of misconception are low because a large number of those interviewed are aware of ways of transmitting the virus. The results are presented in Table 5 and Figure 5. 


\section{Global Journal of Reproductive Medicine}

Table 6: Percentage Distribution of Respondents Personal Risk perception of contracting HIV by State in North-Western Nigeria.

\begin{tabular}{|c|c|c|c|c|c|c|c|}
\hline \multirow[b]{2}{*}{ S/No } & \multirow[b]{2}{*}{ States } & \multicolumn{5}{|c|}{ Respondents opinion about their chances of contracting HIV } & \multirow{2}{*}{$\begin{array}{l}\text { Respondents } \\
\text { aware of AIDS }\end{array}$} \\
\hline & & High chance & Low chance & No risk at all & $\begin{array}{l}\text { Already have } \\
\text { AIDS }\end{array}$ & No response & \\
\hline 1 & Jigawa & 1.2 & 33.2 & 45 & 0.3 & 20 & 756 \\
\hline 2 & Kaduna & 2.2 & 32.2 & 51 & 0.5 & 14.1 & 919 \\
\hline 3 & Kano & 1.6 & 26.9 & 66.4 & 0.6 & 4.3 & 762 \\
\hline 4 & Katsina & 0.6 & 10.4 & 40.4 & 1.3 & 46.7 & 628 \\
\hline 5 & Kebbi & 1.2 & 38.1 & 54.9 & 0.2 & 4.6 & 728 \\
\hline 6 & Sokoto & - & 25.8 & 63.4 & 0.2 & 9.6 & 756 \\
\hline 7 & Zamfara & 0.4 & 47 & 34.7 & 0 & 17.4 & 658 \\
\hline \multicolumn{2}{|c|}{ TOTAL } & 1.2 & 30.5 & 50.8 & 0.4 & 16.7 & 5,207 \\
\hline
\end{tabular}

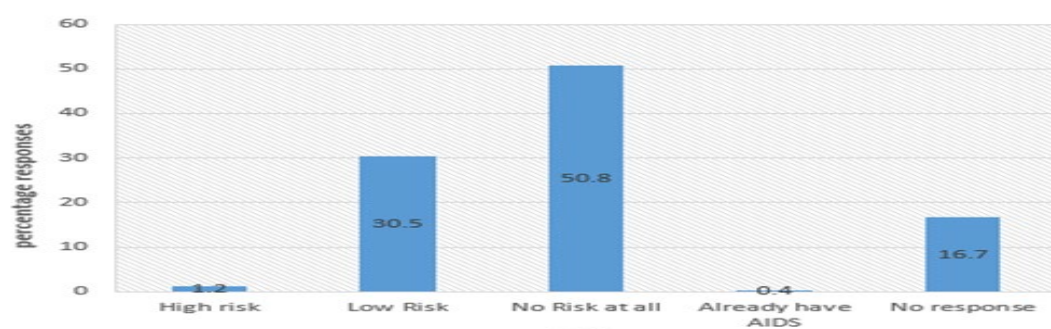

Figure 6: Percentage distribution of Respondents Personal Risk perception of contracting HIV.

Table 7: Percentage Distribution of Respondents who were offered HIV Counselling and Tested for HIV during ANC service by State in NorthWestern Nigeria.

\begin{tabular}{|c|c|c|c|c|}
\hline S/No & States & $\begin{array}{c}\text { offered HIV counseling during last or } \\
\text { current pregnancy while receiving ANC }\end{array}$ & $\begin{array}{c}\text { Tested for HIV during last or current } \\
\text { pregnancy while receiving ANC }\end{array}$ & $\begin{array}{c}\text { Number of women who } \\
\text { had ANC }\end{array}$ \\
\hline 1 & Jigawa & 48.6 & 32.4 & 112 \\
\hline 2 & Kaduna & 79.4 & 58 & 179 \\
\hline 3 & Kano & 46.7 & 46.3 & 148 \\
\hline 4 & Katsina & 34.9 & 27.9 & 136 \\
\hline 5 & Kebbi & 41.4 & 40 & 146 \\
\hline 6 & Sokoto & 78.9 & 7.7 & 151 \\
\hline 7 & Zamfara & 30 & 30 & 115 \\
\hline \multicolumn{2}{|c|}{ TOTAL } & $\mathbf{5 1 . 4}$ & $\mathbf{3 4 . 6}$ & $\mathbf{9 8 7}$ \\
\hline
\end{tabular}

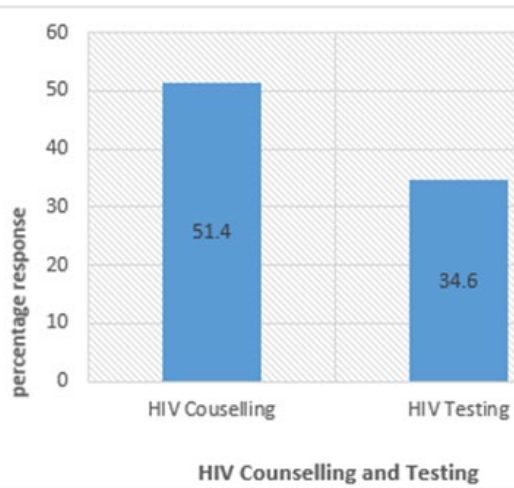

Figure 7: Percentage distribution of respondents who were offered HIV Counselling and Tested for HIV during ANC service. 


\section{Conclusion}

This study finds that awareness and knowledge of HIV/AIDS are high among people of North-Western Nigeria. Virtually all the variables used in the analysis were significantly associated with awareness and knowledge of HIV/AIDS as shown in the tables and chats. Most people have heard of the virus, how it can be transmitted, avoided and prevented. This proportion was highest among the respondents with higher educational attainment compared to those with no formal education but about the same proportion for females and males, as well as respondents from rural and urban areas.

\section{References}

1. (2016) History of HIV - overview. Avert.

2. (2016) Mathias Ihiabe-resonance 2016, Current Affairs, Fireman publication Jos, Plateau state, Nigeria.

3. (2015) Nigeria: Stepping up HIV/AIDS Awareness in Nigeria, Daily Independent (Lagos).

4. (2015) The HIV Epidemic in Nigeria/NACA Nigeria.

5. World Food Programme (2013) Literature review on the impact of education level on HIV/AIDS prevalence rates. Available at: Hivaids clearing house unesco.org/search/resources/Literature Review on the impact of education level on HIV.

6. (2012) National HIV \& AIDS and Reproductive Health Survey (NARHS plus II, 2012) Federal Ministry of Health. Abuja, Nigeria.

7. World Health Organization, Joint United Nations Programme on HIV/ AIDS \& UNICEF (2011) Global HIV/AIDS response epidemic update and health sector progress towards Universal Access progress report 2011. Geneva, Switzerland.

8. Garbati N, Musa A, Abba N, Abdullah A (2011) HIV/AIDS in Northern Nigeria. Journal of Infectious Diseases and Immunity 3(10): 176-182.

9. National HIV Sero-prevalence Sentinel Survey Technical Report (2010). Department of Public Health National AIDS/STI Control Programme.

10. Baker DP, Leon J, Collins JA (2010) Facts, attitudes and health reasoning about HIV and AIDS: explaining the education effect on condom use among adults in Sub-Saharan Africa. AIDS Behav 15(7): 1319-1327.

11. Saad SM (2008) The social sciences, the development programme (LDP) of the United Nations Development Programme (UNDP), Social Sciences and the Complex Problems of Nigeria: Combating HIV and AIDS in Nigeria. Paper presented at the National Conference on Social Sciences and the Challenges of the Millenium Development Goals
(MDGs) in Africa, organized by the Faculty of Social Sciences, University of Maiduguri, Nigeria.

12. Bankole OM, Mabekoje OO (2008) Awareness and Opinions about HIV/AIDS among secondary school teachers in Ogun State, Nigeria. Scientific Research and Essay 3(6): 245-253.

13. (2007) National HIV \& AIDS and Reproductive Health Survey (NARHS Plus 2007 All Sectors) Federal Ministry of Health. Abuja, Nigeria.

14. Bukar A, Olusoji o, Adeleke OA, Danfillo IS, Taiwo 00, et al. (2006) knowledge and perception on HIV/AIDS among the Kanuri and Shuwa people of Northern Nigeria about their traditional practice. Nig J Clin Biomed Res 36(1): 36-43.

15. Sa'ad AM, Bello H (2006) The Meaning and Origin of HIV/AIDS, Its Seriousness, Its Drivers, and Prevention. Paper presented at A ThreeDay Workshop on HIV/AIDS for Primary School Head Teachers in Borno State, Nigeria.

16. Petersen PE (2006) Policy for prevention of oral manifestations in HIV/AIDS: the approach of the WHO Global Oral Health Program. Adv Dent Res 19(1): 17-20.

17. National HIV Sero-prevalence Sentinel Survey (2005) process and Findings, National AIDS/STDs Control Programme (NASCP), Federal Ministry of Health, Abuja, Nigeria.

18. Harry TO, Kyari O, Mohammed I (1992) Prevalence of HIV-infection among pregnant women attending the ante-natal clinic in Maiduguri, North-Eastern Nigeria. Trop Geogr Med 44(3): 238-241.

19. Chiwa Musa Dalah, Singh VV (2017) Survey and Assessment Report of HIV/AIDS Awareness of in North-Eastern Nigeria. International Journals of Advanced Research in Computer Science and Software Engineering 7(11): 105-112.

20. Chiwa, Musa Dalah, Singh VV, Abdalla EM (2018) Statistical survey on Awareness of HIV/AIDS and its impact on Economic development in Northern Nigeria during the period 2010-2015. Journal of Statistical and Econometric Methods 3: 35-62.

21. Badamasi Abba, Singh VV (2018) New odd generalized exponentialexponential distribution: its properties and application. BBOAJ 6(3): $1-6$.

22. Maurya VN, Yusuf Umar Madaki, Singh VV, Babagana M (2015) Application of discriminate analysis on broncho- pulmonary dysplasia among Infants: A case study of UMTH and UDUS hospitals in Maiduguri, Nigeria, American Journal of Theoretical and Applied Statistics 4(2): 44-51.

23. Maurya VN, Yusuf Umar Madaki, Singh VV (2014) Statistical analysis of the rate of kidney (renal) failure. American Journal of Applied Mathematics and Statistics 2(6A): 6-12.

\section{Your next submission with Juniper Publishers will reach you the below assets}

- Quality Editorial service

- Swift Peer Review

- Reprints availability

- E-prints Service

- Manuscript Podcast for convenient understanding

- Global attainment for your research

- Manuscript accessibility in different formats

( Pdf, E-pub, Full Text, Audio)

- Unceasing customer service

Track the below URL for one-step submission

https://juniperpublishers.com/online-submission.php 